Letter Report

\title{
Borehole Flow and Horizontal Hydraulic Conductivity with Depth at Well ER-12-3
}

\author{
prepared by \\ Phil L. Oberlander and Charles E. Russell \\ Division of Hydrologic Sciences \\ Desert Research Institute \\ Nevada System of Higher Education \\ submitted to \\ Nevada Site Office \\ National Nuclear Security Administration \\ U.S. Department of Energy \\ Las Vegas, Nevada
}

September 2005 
Reference herein to any specific commercial product, process, or service by trade name, trademark, manufacturer, or otherwise, does not necessarily constitute or imply its endorsement, recommendation, or favoring by the United States Government or any agency thereof or its contractors or subcontractors. The views and opinions of authors expressed herein do not necessarily state or reflect those of the United States Government or any agency thereof.

This report has been reproduced directly from the best available copy.

Available for sale to the public, in paper, from:

U.S. Department of Commerce

National Technical Information Service

5285 Port Royal Rd.

Springfield, VA 22161

phone: 800.553 .6847

fax: 703.605.6900

email: order@ntis.gov

online ordering: http://www.osti.gov/ordering.htm

Available electronically at http://www.doe.gov/bridge

Available for a processing fee to the U.S. Department of Energy and its contractors, in paper, from:

U.S. Department of Energy

Office of Scientific and Technical Information

P.O. Box 62

Oak Ridge, TN 37831-0062

phone: 865.576 .8401

fax: 865.576.5728

email: reports@adonis.osti.gov 
Letter Report

\title{
Borehole Flow and Horizontal Hydraulic Conductivity with Depth at Well ER-12-3
}

\author{
prepared by \\ Phil L. Oberlander and Charles E. Russell \\ Division of Hydrologic Sciences \\ Desert Research Institute \\ Nevada System of Higher Education \\ submitted to \\ Nevada Site Office \\ National Nuclear Security Administration \\ U.S. Department of Energy \\ Las Vegas, Nevada
}

September 2005

The work upon which this report is based was supported by the U.S. Department of Energy under Contract \#DE-AC52-00NV13609; intended for limited distribution. 



\section{ABSTRACT}

Borehole flow and fluid temperature during pumping were measured at well ER-12-3 at the Nevada Test Site in Nye County, Nevada. This well was constructed to characterize the carbonate aquifer. The well is cased from land surface to the total depth at 1,487 $\mathrm{m}(4,880 \mathrm{ft})$ below ground surface (bgs). Slotted screen is placed in an upper screened section from 1,095 to $1,160 \mathrm{~m}$ bgs $(3,591$ to $3,805 \mathrm{ft}$ bgs $)$ and in the lower screened section from 1,278 to $1,474 \mathrm{~m}$ bgs $(4,191$ to $4,834 \mathrm{ft}$ bgs $)$.

Borehole flow velocity $\left(\mathrm{LT}^{-1}\right)$ with depth was measured with an impeller flowmeter from the top of the screened section to the maximum accessible depth while the well was pumped and under ambient conditions. A complicating factor to data interpretation is that the well was not filter packed and there is significant upward and downward vertical flow in the open annulus under ambient and pumping conditions. The open annulus and large vertical flow velocities in the well casing result in the measured borehole flow rates being potentially highly nonrepresentative of conditions in the aquifer. Hydraulic conductivities calculated under these conditions would require unsupportable assumptions and would be subject to very large uncertainties. Borehole hydraulic conductivities are not presented under these conditions.

\section{ACKNOWLEDGEMENTS}

Grateful acknowledgement is given to the following for their contributions to this report: Mr. Robert Bangerter, Project Manager, U.S. Department of Energy/Nevada Site Office, for funding this project; Desert Research Institute staff, including Charles Russell (Project Manager), David Gillespie, Brad Lyles, and Scott Campbell, for data collection. 


\section{LIST OF ACRONYMS AND ABBREVIATIONS}

bgs below ground surface

$\mathrm{cm}$ centimeters

$\mathrm{d} / \mathrm{m} \quad$ degrees Celsius per meter

DRI Desert Research Institute

EC electrical conductivity

ER Environmental Restoration

$\mathrm{ft}$ feet

$\mathrm{ft} / \mathrm{d} \quad$ feet per day

$\mathrm{ft}^{2 /} \mathrm{d} \quad$ feet squared per day

$\mathrm{ft} / \mathrm{min}$ feet per minute

gpm gallons per minute

in inches

kg kilogram

$\mathrm{L}^{3} / \mathrm{T} \quad$ length cubed per time

$\mathrm{L} / \mathrm{min}$ liters per minute

$\mathrm{m}$ meters

$\mathrm{m} / \mathrm{d}$ meters per day

$\mathrm{m}^{2} / \mathrm{d}$ meters squared per day

$\mathrm{m} / \mathrm{min}$ meters per minute

NAD North American Datum

NTS Nevada Test Site

psi pounds per square inch

UGTA Underground Test Area

UTM Universal Transverse Mercator grid 


\section{INTRODUCTION TO BOREHOLE FLOW LOGGING}

\section{Background}

The U.S. Department of Energy, National Nuclear Security Administration Nevada Site Office (NNSA/NSO) constructed a series of deep characterization and monitoring wells as part of the Underground Test Area (UGTA) project in southern Nevada. The Desert Research Institute (DRI) characterized borehole flow rates as a part of the UGTA project. Borehole flow rates $\left(\mathrm{L}^{3} \mathrm{~T}^{-1}\right)$ with depth were measured under ambient and pumping conditions. Two types of flowmeters were used for this project: a thermal pulse flowmeter constructed by DRI is used to characterize ambient conditions and can detect vertical borehole flow rates as low as 0.015 meters per minute $(\mathrm{m} / \mathrm{min})$ (e.g., 0.05 feet per minute $[\mathrm{ft} / \mathrm{min}]$ ) and an impeller flowmeter was used to characterize borehole flow during well pumping and can detect flow rates as low as 0.75 $\mathrm{m} / \mathrm{min}$ (e.g., $2.5 \mathrm{ft} / \mathrm{min}$ ).

The rate of groundwater inflow to the well is used to calculate the horizontal hydraulic conductivity at depth. Borehole temperature and flow rate measurements were recorded every $0.06 \mathrm{~m}(0.2 \mathrm{ft})$ of depth and averaged over $1.5-\mathrm{m}(5-\mathrm{ft})$ vertical intervals to dampen small-scale measurement variations in the measurement data. Flow measurements were collected from the lower portion of the well casing to the maximum accessible depth in the well. Flow logging did not include the lowest portion of the wells due to the probability of encountering rock detritus and/or instrumentation debris that would damage the borehole flowmeter.

Monitoring well ER-12-3 is located on Rainier Mesa on the Nevada Test Site (NTS) at NAD 27; UTM (Zone 11) coordinates 4,116,592-m northing, 569,748-m easting. The land surface elevation is $2,251 \mathrm{~m}(7,385 \mathrm{ft})$. The well was flow logged in June and July 2005 by DRI staff. This letter report presents the interpretation of borehole flow, temperature, and hydraulic conductivity within the well. The location of the well with respect to the Nevada Test Site is illustrated in Figure 1.

Borehole flow measurement was conducted under two conditions: 1) the logged well was not being pumped and 2) the well was logged while being pumped (i.e., stressed flow logging). Logging under ambient conditions was conducted with two different types of flowmeter. A thermal pulse flowmeter was used to measure subtle vertical flow rates and an impeller flowmeter was used to measure more rapid vertical flow rates.

During the stressed flow logging, the pumping rate was increased stepwise between sets of logging runs. The selected pumping rates represent the maximum and minimum flow rates based on water level and the pump requirement for cooling water. Flow logging was conducted at nominal line speeds (the speed at which the geophysical tools are raised or lowered in the well) of $6,9,12$, and $18 \mathrm{~m} / \mathrm{min}(20,30,40$, and $60 \mathrm{ft} / \mathrm{min})$. The different combinations of logging speeds and pumping rates provide 12 unique data sets for pumping conditions that aid in reducing measurement uncertainty and mechanical bias. 

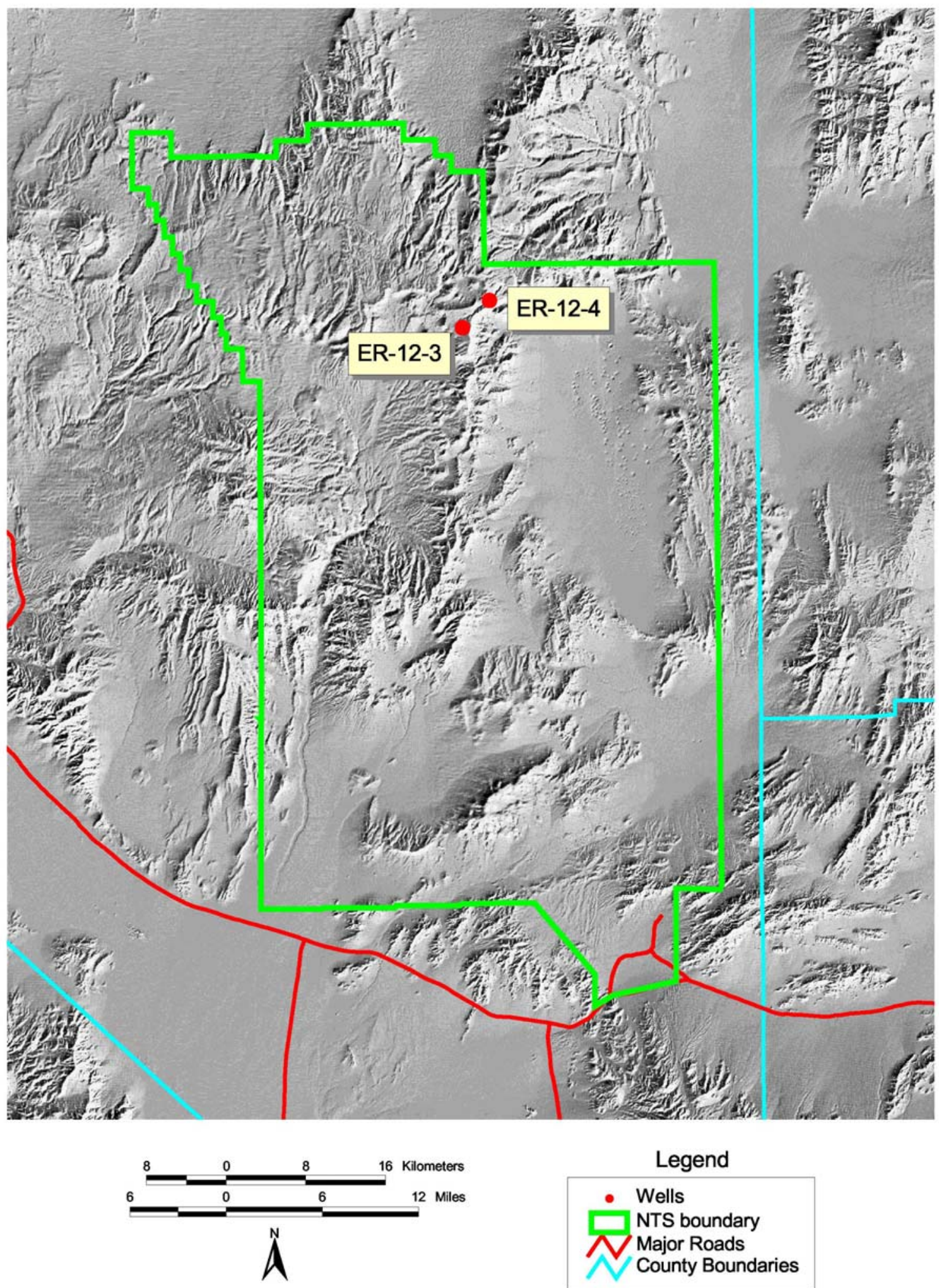

Legend

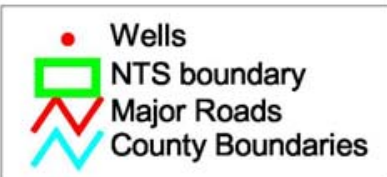

Figure 1. Location of wells ER-12-3 and ER-12-4 at the Nevada Test Site. 


\section{Flow Logging Equipment}

The UGTA program uses a high-precision, wireline borehole flowmeter that can retract the impeller blades to enter 7-cm (2.75-inch) diameter access tubing that extends past the pump and submersible motor assembly. As the flowmeter exits the access tube at depth, the impellers unfold and extend to nearly $14 \mathrm{~cm}$ (5.5 inches). The borehole flowmeter uses lightweight impellers and minimal shaft seals to allow rotation at fluid velocities as low as $0.75 \mathrm{~m} / \mathrm{min}$. The flow rate logging equipment consists of Computalog ${ }^{\circledR}$ Flexstak tools arranged from top to bottom in the following order: telemetry cartridge, centralizer, temperature tool, centralizer, and the borehole flowmeter with a coaxial centralizer.

The temperature tool is rated for a maximum of $176^{\circ} \mathrm{C}$ and the tool string is rated to a maximum pressure of 117.2 megapascals (17,000 pounds per square inch [psi]). Three centralizers are used to ensure that the tool string is centered in the casing. Temperature measurements supplement the borehole flow rate information.

The borehole flow-logging computer records impeller rotation rate (revolutions per second), temperature, cable speed $\left(\mathrm{LT}^{-1}\right)$, and depth (L). An interface cable is connected between the flowmeter at land surface and the borehole flow-logging computer. The well discharge rate $\left(\mathrm{L}^{3} \mathrm{~T}^{-1}\right)$ at land surface and the downhole borehole flow rate $\left(\mathrm{L}^{3} \mathrm{~T}^{-1}\right)$ are recorded simultaneously. Borehole flow rates and fluid temperatures are measured every six centimeters while the borehole flowmeter is continuously lowered or raised (i.e., a trolling flowmeter). Recording borehole flow rate and temperature measurements every six centimeters is an UGTA data requirement to aid in accurately identifying the locations where there is groundwater inflow at fractures. In a 1,000-m long water column, this measurement scheme produces about 16,000 depth-specific borehole flow measurements for each log. As a normal practice, the data are not interpreted at this spatial scale. The data are typically interpreted at a vertical scale of $1.5 \mathrm{~m}$ or greater to reduce the measurement noise in the calculated hydraulic conductivities. The $6-\mathrm{cm}$ data spacing is used to accurately align the instrument measurements with cased sections, screen intervals (if any), and changes in bore diameter.

A second type of flowmeter used to characterize UGTA wells is a thermal pulse flowmeter (thermal flowmeter). This flowmeter electrically heats a wire element and detects the heated water that moves upward or downward with the vertical flow in the well. The thermal flowmeter is calibrated under laboratory conditions to account for buoyancy effects. This flowmeter was used to characterize ER-12-3 under ambient flow (i.e., nonpumping) conditions and can detect borehole flow rates much lower than the impeller flowmeter.

\section{ANALYSIS METHODOLOGY}

\section{Hydraulic Conductivity Determined from Borehole Flow Rates and Pressures}

Horizontal hydraulic conductivity with depth is calculated based on measurement of the borehole flow rate with depth while the well is pumped at a constant rate. The borehole flow rate data are interpreted using the methodology developed by Rehfeldt et al. (1989), in which the hydraulic conductivity of an interval is a function of the interval's groundwater contribution to the well discharge and the change in fluid pressure (i.e., water level drawdown) caused by pumping. The hydraulic conductivity over an interval under steady-state conditions is defined as 


$$
K_{i}=\frac{\left(q_{o}-q_{n}\right)}{\left(2 * \pi *\left(h_{o}-h_{n}\right)\right)} \ln \frac{R a}{r o}
$$

where: $\mathrm{K}_{\mathrm{i}}$ is the interval hydraulic conductivity $\left(\mathrm{LT}^{-1}\right)$,

$\mathrm{q}_{\mathrm{o}}$ is the ambient flux through the aquifer for an interval $\left(\mathrm{L}^{2} \mathrm{~T}^{-1}\right)$,

$\mathrm{q}_{\mathrm{n}}$ is the pumping flux through the aquifer for an interval $\left(\mathrm{L}^{2} \mathrm{~T}^{-1}\right)$,

$\mathrm{h}_{\mathrm{o}}$ is the pressure at an interval at ambient conditions (L),

$\mathrm{h}_{\mathrm{n}}$ is the pressure at an interval under pumping conditions (L),

$\mathrm{Ra}$ is the effective hydraulic radius during pumping $(\mathrm{L})$, and

ro is the radius of the borehole (L).

The information necessary to apply Equation (1) is provided by aquifer testing and borehole flow logging. Groundwater inflow rates are taken as the difference between successive depth-dependent borehole flow rates. This assumes that all changes in borehole flow rate are caused by groundwater inflow from the formation. The effective hydraulic radius is estimated from aquifer test parameters and includes an adjustment for deliberate changes in pumping rate between certain flow logs. The radius of the borehole within each calculation interval is taken from caliper log measurements of the bore before placing casing in the well.

Fluid pressure with depth necessary for Equation (1) was not measured directly during flow logging. This is because a pressure transducer capable of operating at a high level of precision over a very large pressure range was unavailable. Pressure with depth is estimated based on measured fluid temperature, height of the fluid column, and the well-known temperature dependencies of fluid density and fluid compressibility. Where the fluid in the well is flowing, the effects of temperature-dependent viscosity and friction loss (laminar and turbulent conditions) are used in the pressure calculation based on standard engineering equations for flow in pipes. The pressure estimations under nonpumping conditions have been compared to values measured by transducers set at depths of 235 to $1,101 \mathrm{~m}$ (771 to 3,613 ft) at other UGTA wells. Pressure estimation errors are generally between 6.9 and 27.6 kilopascals ( 1 and 3 psi).

Horizontal hydraulic conductivity calculated in Equation (1) is based on the change in pressure at a specific depth caused by pumping and not the absolute value of pressure. Therefore, a minor systematic inaccuracy in the estimate of ambient and pumping pressures becomes less important to the analysis.

The physical processes not included in the pressure calculation are:

- the amount of total dissolved and suspended solids, which increases pressure with increasing concentration, and

- dissolved and entrained gasses, which decrease fluid pressure.

Exclusion of these opposing processes does not appear to affect significantly the accuracy of the static fluid pressure prediction. 
Pumping causes two major pressure effects within the well. The first effect is the pressure change caused by lessening the height of the fluid column by inducing water-level drawdown. The second pumping effect is the typical replacement of the ambient borehole fluid with a fluid of a different temperature and density. When the replaced borehole fluid has lesser density (i.e., a warmer fluid), the fluid has less mass per unit volume than the more dense fluid initially in the well. If the borehole fluid temperature increased in a nonpumping well, the pressure at depth would remain constant and there would be a corresponding increase in water-level elevation.

In pumping wells, the effect of fluid density decrease functions in concert with the waterlevel drawdown to decrease pressure at depth. The density effect on fluid pressure is not uniform with depth and become more pronounced over longer fluid columns. This can be illustrated by considering the pressure change during pumping at two locations within the well, at the water surface and with increasing depth. The fluid pressure in a moving water column is described (Vennard and Street, 1975) as

$$
\mathrm{P}_{\mathrm{t}}=(\rho * \mathrm{~g} * \mathrm{~h})+\left(1 / 2 \rho_{\mathrm{p}} * \mathrm{~V}^{2}\right)+\mathrm{P}_{\mathrm{e}}
$$

where $\mathrm{P}_{\mathrm{t}}$ is the total pressure at the measurement point $\left(\mathrm{ML}^{-1} \mathrm{~T}^{-2}\right)$,

$\rho$ is the effective fluid density above the measurement point $\left(\mathrm{ML}^{-3}\right)$,

$\mathrm{g}$ is gravitational acceleration at the measurement point $\left(\mathrm{LT}^{-2}\right)$,

$\mathrm{h}$ is the height of the fluid column above the measurement point (L),

$\rho_{\mathrm{p}}$ is the fluid density at the measurement point $\left(\mathrm{ML}^{-3}\right)$,

$\mathrm{V}$ is the fluid velocity at the measurement point $(\mathrm{L} / \mathrm{T})$, and

$\mathrm{P}_{\mathrm{e}}$ is the externally applied pressure $\left(\mathrm{ML}^{-1} \mathrm{~T}^{-2}\right)$.

There is no externally applied pressure in the case of boreholes except atmospheric pressure and aquifer matrix compression. The external pressure $\left(\mathrm{P}_{\mathrm{e}}\right)$ is assumed zero. The borehole fluid near the water-level surface is many meters above the pump intake and the fluid velocity $(\mathrm{V})$ is essentially zero. The hydraulic head pressure can then be calculated by the simplified equation

$$
\mathrm{P}=\left(\rho^{*} \mathrm{~g} * \mathrm{~h}\right)
$$

where the terms are as above.

First, consider the fluid pressure change at the top of the water column during pumping. The fluid pressure change is determined with Equation (3) by subtracting the pressure under pumping conditions from the fluid pressure under nonpumping conditions. At the top of the water column during pumping, the height of the fluid column (h) is zero and the fluid pressure at the water surface is zero. Therefore, at the pumping water level, the change in fluid pressure is caused solely by the water-level drawdown (i.e., removal of the fluid above the pumping water level).

Secondly, consider pressure at increasing depth. At depth, the pressure change caused by pumping includes the constant pressure decrease caused by drawdown (i.e., the change in (h)) and the pressure change caused by the change in fluid density $(\rho)$ between a specific depth and the top of the fluid column. With increasing depth, the relatively small changes in fluid density 
caused by pumping act over longer fluid columns and the effect on fluid pressure change becomes more pronounced. Therefore, when the fluid density changes with depth during pumping, the resulting fluid pressure change with depth is not uniform. In most UGTA wells, there are notable variations in fluid temperature and fluid density with depth under nonpumping and pumping conditions. Therefore, the fluid pressure change caused by pumping is variable with depth and nonlinear. When fluid density varies significantly, drawdown during pumping does not represent the total pressure change at depth. In the deep UGTA wells such as ER-EC-1, the pressure change at the bottom of the well caused by replacement of cooler fluids with warmer fluids during pumping was equivalent to over $3 \mathrm{~m}(10 \mathrm{ft})$ of additional water-level drawdown. In UGTA well ER-12-3, the change in thermally induced density has an insignificant affect on fluid pressure.

The apparent radius of influence used in Equation (1) is calculated based on the Thiem equation (Driscoll, 1986) and calculated transmissivity, estimated storativity, pumping rate, well diameter, and period of pumping. An apparent radius of influence is calculated for each pumping rate. Because the well was not allowed to fully recover between the changes in pumping rates, the effective time of pumping is used to calculate the apparent radius of influence in a manner similar to interpreting a step drawdown test based on the Cooper-Jacob Step Pumping Method (Kruseman and de Ridder, 1970). These interpretive techniques assume that the flow field during well logging is:

- fully radial,

- strictly horizontal, and

- at steady state.

These assumptions are probably not fully met in the fractured carbonate aquifer underlying permeable tuff. The affects of these simplifying assumptions are not quantified.

\section{Flow Log Specific Calibration}

The borehole flowmeter records with depth the impeller revolution rate as counts per second. A separate thermistor measures fluid temperature. Borehole flow rates are plotted in the field based on a simple calibration scheme. However, the borehole flowmeter is subject to mechanical wear on the impeller shaft bearings and grease and grit adhering to the impeller blades. The source of this material is believed to be the grease used on casing threads and a combination of grit from the formation and scale from the mild steel access tubing. Therefore, the borehole flow logs are post-processed to calibrate each log individually to account for the time-varying instrument condition. Combining individual logs without accounting for changes in mechanical efficiency of the borehole flowmeter would result in information degradation.

The individual flow logs are downloaded from the geophysical logging computer as spreadsheet files. The impeller rotation rate and cable travel speed are post-processed along with well construction information to refine the borehole flow calculations. Specifically, the effects of pumping rate, well diameter, vertical travel speed and direction of the logging tool (cable line speed), and instrument calibration are considered in calculating the final borehole flow rate. 
A consideration in flowmeter calibration is accounting for the apparent flow caused by moving the flowmeter through the water column while measuring borehole flow rates. The casing diameter and the travel speed of the flowmeter are used to calculate the apparent volumetric borehole flow rate. The apparent flow is assumed to occur as slug flow without a velocity change across the well diameter. This assumption is slightly simplistic compared to the actual borehole conditions (i.e., nonlaminar pipe flow). Small changes in casing diameter or inaccuracy in cable travel speed would also affect the predicted borehole flow rate and flowmeter calibration.

Each borehole flow log includes logging about $12 \mathrm{~m}$ (40 ft) within the blank casing above the interval open to the aquifer. This portion of the log is important because within this cased interval the borehole flow rate is the same as the well discharge.

The borehole flowmeter is recalibrated for each logging run by comparing downhole flow rate above the open bore to the land surface flowmeter. The surface flowmeter used to control the pumping rate is magnetic and the installation has an appropriate length of straight pipe upgradient and downgradient of the flowmeter to limit turbulence. Typically, the surface flowmeter exhibits very steady readings with standard deviation of about five liters per minute (L/min). The geophysical logging computer is linked via a communications cable to the land surface flowmeter and simultaneously records readings by both the land surface flowmeter and the borehole flowmeter. When the borehole flowmeter is positioned in the casing above the open bore, the two meters should provide similar results. Knowing the actual borehole flow rate from the land surface flowmeter, the borehole flowmeter can be recalibrated for each log. Recalibration consists of calculating the slope and y-intercept of a linear equation relating impeller rotation rate to the known well discharge rate.

Recalibration occurs only in the upper portion of each flow log. Sometimes the calibration section is logged at the beginning of the log (e.g., when logging downward) and sometimes at the end of a $\log$ (e.g., when logging upward). Ideally, there would be a section of blank casing located at the bottom of the well so that the flowmeter could be calibrated at the top of the log to the known pumping rate and again at the bottom of the log under a no-flow condition. Calibration parameters are also adjusted for changes in borehole diameter based on a caliper log.

Flow rates in the cased well are reported only as measured within the $14-\mathrm{cm}$ (5.5-inch) casing. Borehole flow rates outside the casing and in the annulus between the casing and the borehole wall are difficult to extrapolate because the flow velocity outside the casing may not be the same as inside the casing. The calculated flow rates in the screened sections for upward logging and downward logging at the same line speed produced very different results. Additionally, the discrepancy between the upward and downward flow rates increased with logging line speed. This effect strongly indicates that the borehole flowmeter restricted flow in the casing and that water was being pushed through the well screen and into the open annulus. Typical well construction provides a filter pack that presents flow resistance and most of the fluid remains inside the screened interval. Averaging flow logs conducted at the same line speed in upward and downward directions removed most of the flow effect and determined representative values for flow at that pumping rate. 


\section{ABSTRACTION OF FLOW LOGGING INFORMATION}

The borehole flowmeter impeller rotation rate is recorded every six centimeters of logging depth. The relatively short recording distance of just a few centimeters allows accurate depth identification of abrupt borehole flow features such as large groundwater inflow rates at discrete fractures. The six-centimeters recording distance also causes the logging system to base the impeller rotation rate on a limited number of rotations. The rotation rate is calculated by the logging computer based on four discrete "counts" per rotation. At the slowest logging line speed of about six meters per minute there are 0.6 seconds of impeller rotations available to calculate the average rotation rate. Logging at higher travel speeds of 9.1 to $12.2 \mathrm{~m} / \mathrm{min}$ reduces the recording interval to every 0.4 to 0.3 seconds, respectively. The short time period available for data collection limits the number of impeller rotations (or partial rotations) before data recording. Therefore, apparent short-term flow rate variations are imbedded in the data. It is important to reduce the small-scale flow rate variations caused by measurement noise so that they are not attributed to changes in borehole flow rate or hydraulic conductivity. The field measurements are post-processed using more sophisticated techniques than the field plot calibration to calculate hydraulic conductivity with depth and includes:

- averaging within and among the borehole flow logs,

- removing spurious data within a log by filtering,

- smoothing the small-scale instrument noise by averaging the higher quality data among logs at a common depth and pumping rate,

- reducing data volume for easier handling and smoothing data by averaging over vertical intervals within the composite log for a given pumping rate, and

- abstracting the essential flow data trends at an appropriate spatial scale within the open bores.

These processes are applied in a specific sequence and at appropriate scales to preserve hydrogeologic information as described in Oberlander and Russell (2003). A brief discussion of the major data processing steps is provided below.

\section{Removing Impeller Stalls}

Data filtering is used to remove spurious data within an individual flow log. At certain upward logging line speeds, the velocity of the fluid column and flowmeter are nearly the same. Under this condition, there is insufficient flow past the impeller to cause rotation (i.e., the impeller stalls). As the upward velocity of fluid in the borehole changes with the groundwater inflow, the impeller resumes rotation.

Impeller stalling is addressed by trolling the flowmeter at up to four different travel speeds and operating the well at up to three pumping rates. This causes stall locations (if any) to be over different depth intervals for each flow log. Under ideal conditions, the flowmeter rotates when the vertical flow velocity is greater than about $0.75 \mathrm{~m} / \mathrm{min}$. Impeller stalls are readily indicated by locations of a few meters to a few tens of meters in length where there was no impeller rotation. Impeller stalls are bracketed by the minimum upward and downward flow velocity sufficient to cause rotation. Within this velocity range, it is not possible to calculate an 
accurate borehole flow rate, and the data for that portion of the flow log are omitted from the analysis.

\section{Filtering and Compositing among Logs Collected at a Common Pumping Rate}

More subjective is determining where the flowmeter was experiencing difficulty in freely rotating or had been perturbed mechanically or hydraulically, causing a spurious calculated flow rate. A comparison of borehole flow rates measured at the same pumping rate and depth indicates the consistency of calculated borehole flow rates. Ideally, borehole flow measurements collected at the same depth and the same pumping rate should be nearly the same value. Experience with these logs indicates that there can be significant differences in flowmeter values, even after individually calibrating the flow rate logs and removing impeller stalls. Some of the differences in the apparent flow rates are believed to be caused by sudden changes in flowmeter efficiency during logging. If grit or grease affects the impeller efficiency, suddenly or progressively during a log, then the calibration coefficients calculated at the beginning or end of a log can be somewhat inaccurate and produce anomalous values.

Variability among the borehole flow rates is evaluated by calculating the standard deviation of the three to six values collected at the same depth and pumping rate. The standard deviation of only a few values does not reflect the same statistic as if there were many borehole flow measurements at the same pumping rate at the same depth location. If there were many flow measurements at the same depth and pumping rate, an evaluation of statistical confidence and outliers could be performed according to standard statistical practices. The standard deviation used within this context is only to identify which log is causing the largest difference among values. The identification of anomalous data is performed at the spatial logging scale of six centimeters because irregular flow features often occur over small vertical distances.

The anomalous values are removed by a filter that evaluates the borehole flow rates at a constant depth and identifies which flow log's rate is most different from the other rates. If the difference is greater than a specified threshold value (i.e., the filter strength), that log's flow rate is removed from the analysis. The filter strength is adjusted based on judgment to account for the individual quality of each logging suite. The data are filtered at various levels to determine qualitatively when most of the anomalous data have been removed. Application of a filter to remove anomalous data also has the potential affect of smoothing the data and disrupting the calculated mass balance within the borehole, depending on the amount of filtering selected. The minimum amount of filtering necessary to remove the largest differences between flow rate measurements is used.

\section{Compositing Flow Logs at a Constant Flow Rate}

The individual flow logs at a common pumping rate are composited after removing anomalous values. By logging at various line speeds within a common pumping rate, information gained at one logging line speed may not be recognized at another line speed because of impeller stalling. By compositing the individual logs collected at a common pumping rate, data gaps are filled by information from other logs. This effectively combines the information collected at various logging speeds into a single representation of flow in the well for each pumping rate and smoothes the measurements. The flow rate measurements made at a common pumping rate and depth are composited by averaging at the measurement scale of six centimeters. These values 
exhibit flow rate variations about the mean that can be reduced to better define borehole conditions and a more confident interpretation of hydraulic conductivity.

\section{Hydraulic Conductivity Calculation Intervals}

The essential characteristics of flow and temperature in the composited borehole values are abstracted by vertically averaging the values over a depth interval. The length of the calculation intervals is important because they are used to estimate the change in borehole flow rate and fluid pressure, and calculate the hydraulic conductivity with depth. There are two important and competing objectives when vertically averaging flow rate data, preserving spatial resolution and reducing uncertainty. Long vertical calculation intervals will average more data and reduce the amount of uncertainty in the borehole flow rate. This allows calculation of relatively small values of hydraulic conductivity because there is more confidence that the change in borehole flow rate with depth can be attributed to groundwater inflow. However, long calculation intervals lose spatial resolution and the depth location of abrupt hydraulic features becomes less certain. If the hydraulic conductivity of the geologic units was relatively uniform with depth, the change in borehole flow rates with depth would occur smoothly over long vertical distances. Under these conditions, the calculated hydraulic conductivity values would be somewhat insensitive to the vertical calculation interval. Calculation intervals for the ER-12-3 are a nominal $6.1 \mathrm{~m}(20 \mathrm{ft})$.

\section{MONITORING WELL ER-12-3}

\section{Well Construction}

Monitoring well ER-12-3 is located on Rainier Mesa at the NTS at NAD 27; UTM (Zone 11) coordinates $4,116,592-\mathrm{m}$ northing, 569,748-m easting. The land surface elevation is $2,251 \mathrm{~m}$ $(7,385 \mathrm{ft})$. The well construction and completion are summarized in Table 1 . The well is cased and screened in the logged section. A factor that disturbed borehole flow during logging was an open annulus between the well screen and the well bore. This zone provided an open conduit for water to flow outside the well casing during well logging. The well was borehole flow logged in June and July 2005 by DRI staff. The summary of each borehole flow log is presented in Table 2. The maximum accessible depth to the logging tools was about $1,477 \mathrm{~m}(4,845 \mathrm{ft})$ below ground surface (bgs).

Table 1. Summary of well construction for UGTA Monitoring Well ER-12-3.

\begin{tabular}{ccccl}
\hline $\begin{array}{c}\text { Depth Interval } \\
(\mathrm{m})\end{array}$ & $\begin{array}{c}\text { Depth Interval } \\
(\mathrm{ft})\end{array}$ & $\begin{array}{c}\text { Diameter } \\
(\mathrm{cm})\end{array}$ & $\begin{array}{c}\text { Diameter } \\
(\mathrm{in})\end{array}$ & \multicolumn{1}{c}{ Comments } \\
\hline $0-799$ & $0-2,622$ & 47.0 & 18.5 & borehole diameter \\
$799-1,496$ & $2,622-4,908$ & 31.1 & 12.25 & borehole diameter \\
$606-678$ & $1,988-2,225$ & 47.0 & 18.5 & annulus cement \\
$0-1,068$ & $0-3,505$ & 19.4 & 7.625 & blank casing \\
$1,068-1,095$ & $3,503-3,591$ & 14.0 & 5.5 & blank casing \\
$1,095-1,160$ & $3,591-3,805$ & 14.0 & 5.5 & well screen \\
$1,160-1,278$ & $3,805-4,192$ & 14.0 & 5.5 & blank casing \\
$1,278-1,473$ & $4,192-4,834$ & 14.0 & 5.5 & well screen \\
$1,473-1,487$ & $4,834-4,880$ & 14.0 & 5.5 & blank casing, bullnose \\
\hline
\end{tabular}


Table 2. Impeller borehole flow logs for UGTA Monitoring Well ER-12-3 (June and July 2005). Downward logging is indicated by a negative sign.

\begin{tabular}{ccccc}
\hline $\begin{array}{c}\text { Log } \\
\text { Designation }\end{array}$ & $\begin{array}{c}\text { Pumping Rate } \\
(\mathrm{L} / \mathrm{min})\end{array}$ & $\begin{array}{c}\text { Pumping Rate } \\
(\mathrm{gpm})\end{array}$ & $\begin{array}{c}\text { Line Speed } \\
(\mathrm{m} / \mathrm{min})\end{array}$ & $\begin{array}{c}\text { Line Speed } \\
(\mathrm{ft} / \mathrm{min})\end{array}$ \\
\hline MOV 01 & 112.0 & 29.6 & -5.9 & -19.3 \\
MOV 02 & 112.0 & 29.6 & 6.3 & 20.8 \\
MOV 03 & 112.0 & 29.6 & -12.7 & -41.6 \\
MOV 04 & 112.0 & 29.6 & 13.1 & 42.9 \\
MOV 05 & 112.0 & 29.6 & -18.9 & -61.9 \\
MOV 06 & 112.0 & 29.6 & 19.5 & 64.0 \\
MOV 07 & 79.5 & 21.0 & -6.5 & -21.3 \\
MOV 08 & 79.1 & 20.9 & 6.7 & 22.0 \\
MOV 09 & 79.1 & 20.9 & -12.7 & -41.6 \\
MOV 10 & 79.1 & 20.9 & 13.0 & 42.5 \\
MOV 11 & 79.5 & 21.0 & -9.6 & -31.6 \\
MOV 12 & 79.1 & 20.9 & 9.5 & 31.2 \\
MOV 13 & 0.0 & 0.0 & -6.1 & -20.1 \\
MOV 14 & 0.0 & 0.0 & 6.7 & 21.9 \\
MOV 15 & 0.0 & 0.0 & -12.8 & -42.0 \\
MOV 16 & 0.0 & 0.0 & 13.6 & 44.5 \\
\hline
\end{tabular}

\section{Ambient Flow in the Well Bore}

The thermal pulse flowmeter was used to measure vertical flow in the well under unpumped conditions. The thermal flowmeter measurements are taken while the flowmeter is stationary in the well. The ambient flow measured in the uncased well is presented in Table 3. These data indicate an upward vertical flow above $1,372 \mathrm{~m}(4,500 \mathrm{ft})$ and a downward vertical hydraulic gradient below $1,402 \mathrm{~m} \mathrm{bgs}(4,600 \mathrm{ft}$ bgs). Groundwater is interpreted as entering the bore between 1,372 and 1,402 $\mathrm{m}$ bgs (4,500 and 4,600 ft bgs) and flowing both upward and downward. The upward ambient flow in the uncased well decreased upward, indicating the formation up to $955 \mathrm{~m}$ bgs $(3,133 \mathrm{ft}$ bgs $)$ was taking water. Ambient flow in the uncased well below $1,372 \mathrm{~m}$ bgs $(4,500 \mathrm{ft} \mathrm{bgs})$ increases downward, indicating the formation was making water.

Table 3. Ambient flow in the uncased bore for UGTA Monitoring Well ER-12-3.

\begin{tabular}{cccc}
\hline Depth $(\mathrm{m})$ & Depth $(\mathrm{ft})$ & Flow Rate $(\mathrm{L} / \mathrm{m})$ & Flow Rate $(\mathrm{gpm})$ \\
\hline 954.9 & 3,133 & 0.333 & 0.09 \\
990.6 & 3,250 & 0.382 & 0.10 \\
$1,013.5$ & 3,325 & 0.462 & 0.12 \\
$1,036.3$ & 3,400 & 0.606 & 0.16 \\
$1,097.3$ & 3,600 & 0.462 & 0.12 \\
$1,158.2$ & 3,800 & 0.439 & 0.12 \\
$1,219.2$ & 4,000 & 0.708 & 0.19 \\
$1,280.2$ & 4,200 & 0.678 & 0.18 \\
$1,341.1$ & 4,400 & 0.999 & 0.26 \\
$1,371.6$ & 4,500 & 1.151 & 0.30 \\
$1,402.1$ & 4,600 & -2.775 & -0.73 \\
$1,432.6$ & 4,700 & -2.960 & -0.78 \\
$1,485.9$ & 4,875 & -4.069 & -1.08 \\
\hline
\end{tabular}


The well was logged with the thermal pulse flowmeter a second time after well casing and well screen were installed. The borehole flow rates were greater than $1.5 \mathrm{~m} / \mathrm{min}(5 \mathrm{ft} / \mathrm{min})$ and beyond the instrument's capacity to quantify. The well was then logged with the impeller flowmeter to better define these unexpectedly higher flow rates.

The ambient flow in the cased well is illustrated in Figure 2 and is markedly different than the flow in the open bore. Flow in the upper screened section was upward above $1,149 \mathrm{~m}$ $(3,771 \mathrm{ft})$, reaching a maximum of about $3.4 \mathrm{~m} / \mathrm{min}(11 \mathrm{ft} / \mathrm{min})$ at the top of the screened section. The fluid moving upward past the top of the upper screened section is assumed to exit the well between the top of the well screen at $1,095 \mathrm{~m} \mathrm{bgs}(3,591 \mathrm{ft}$ bgs $)$ and the cement plug at $678 \mathrm{~m}$ bgs $(2,225 \mathrm{ft}$ bgs).

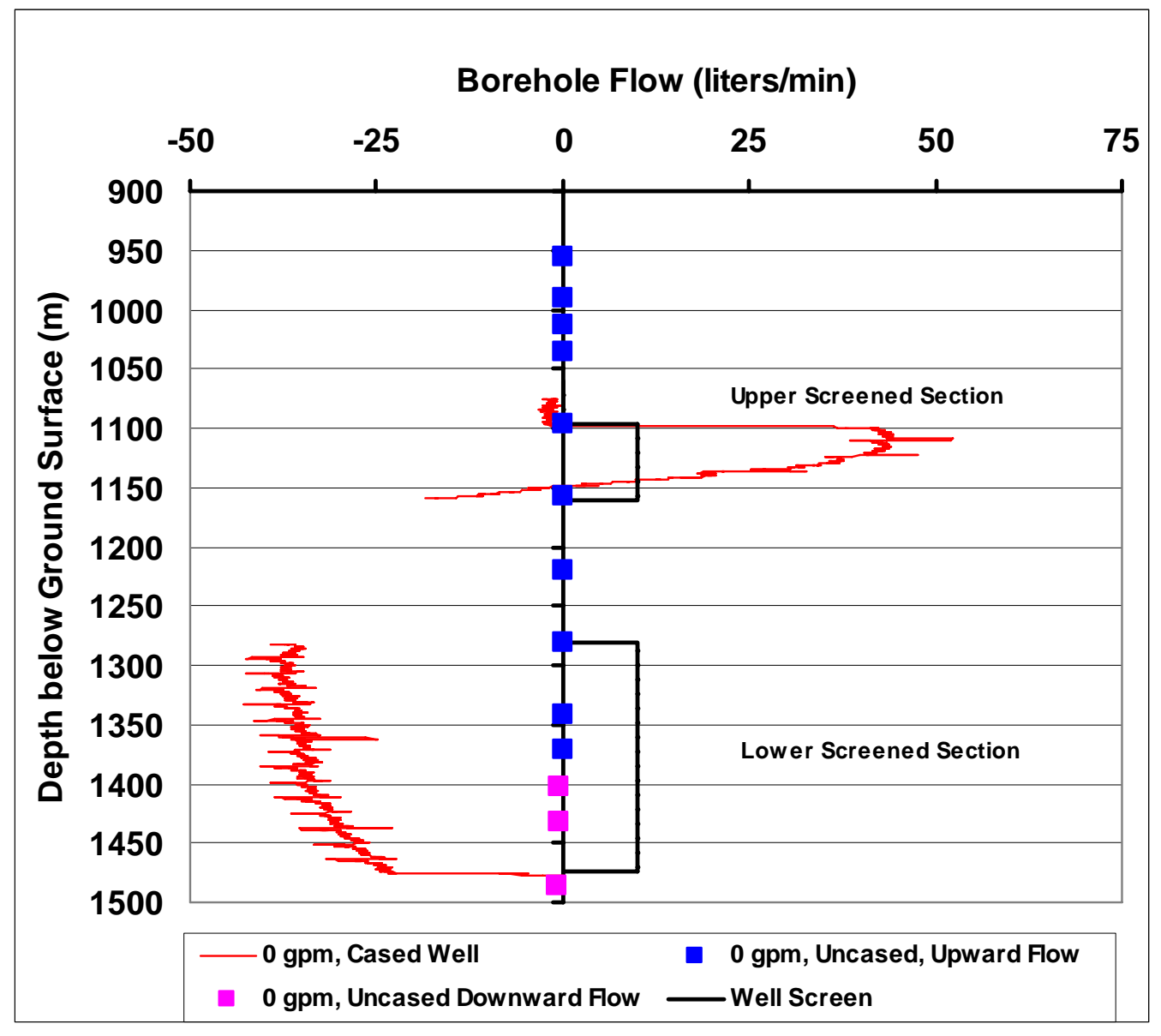

Figure 2. Ambient flow in the well casing.

Flow was downward below $1,149 \mathrm{~m}$ bgs $(3,771 \mathrm{ft}$ bgs), reaching a maximum of about $-4.1 \mathrm{~m} / \mathrm{min}(-13.5 \mathrm{ft} / \mathrm{min})$ at the bottom of the upper screened section. In the lower screened section, the flow was always downward at a maximum of about $-2.9 \mathrm{~m} / \mathrm{min}(-9.5 \mathrm{ft} / \mathrm{min})$ at the top of the screened section and decreasing to about $-1.9 \mathrm{~m} / \mathrm{min}(-6.5 \mathrm{ft} / \mathrm{min})$ at the bottom of the screened section. These values are illustrated in Figure 2. The regularly spaced "spikes and dips" in the flow readings are where the flowmeter passed a casing connection and the internal diameter of the casing is less than the nominal internal diameter. 
The large changes in borehole flow after installing well casing are not attributable to a specific event or hydraulic mechanism. A possible explanation is that the well was not developed until after the casing was installed in the well bore. When logged with the borehole flowmeter, there apparently had been a major change in groundwater inflow and outflow rates and locations below the cement casing seal at $678 \mathrm{~m}$ bgs $(2,225 \mathrm{ft}$ bgs $)$. The cement casing seal is above the static water level at about $950 \mathrm{~m}(3,117 \mathrm{ft})$.

Because the flow rates measured by the impeller are so large, these changes in flow rate are believed to be representative of actual borehole conditions. This conclusion is supported by a flow rate too high for the thermal pulse flowmeter to measure and stalling of the impeller flowmeter (insufficient fluid velocity past the meter to cause the impeller to rotate) when logging downward with a line speed of $6 \mathrm{~m} / \mathrm{min}(20 \mathrm{ft} / \mathrm{min})$.

\section{Water-producing Zones under Stressed Conditions}

Vertical profiles of borehole flow rates were observed at a nominal 76 and $114 \mathrm{~L} / \mathrm{min}(20$ and $30 \mathrm{gpm}$ ). The indicated borehole flow rates are illustrated in Figure 3 with the ambient flow $\log$ for the cased well included.

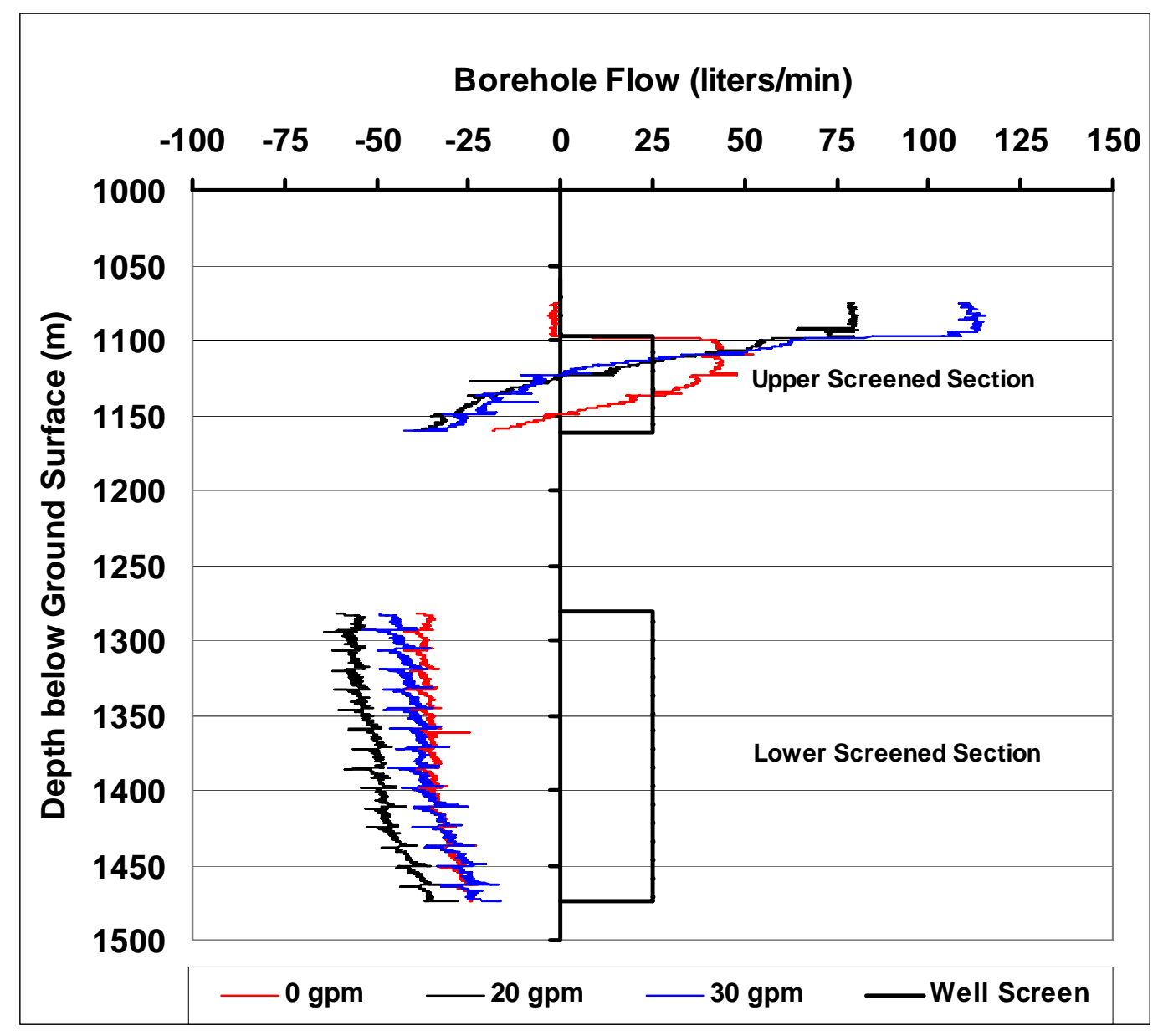

Figure 3. Borehole flow under ambient and pumping conditions. 
The major observations of the borehole flow logs are:

- borehole flow rates in upper screened section are very similar while pumping at 76 and 114 1/min (20 and $30 \mathrm{gpm}$ ); the flow rates diverge significantly only at the very top of the upper screened section,

- pumping caused the hydraulic divide between upward and downward borehole flow to migrate upward from $1,149 \mathrm{~m}$ bgs $(3,771 \mathrm{ft}$ bgs) under ambient conditions to $1,126 \mathrm{~m}$ bgs $(3,694 \mathrm{ft}$ bgs $)$, and

- downward flow in the lower screen section decreased with depth during pumping as it did under ambient conditions.

- These results have inconsistencies that are not readily explained by a simple conceptual model. The inconsistent features of the ambient and pumping logs include:

- the ambient flow rate increased appreciably when the well was cased,

- downward flow in the lower screened section is greatest while pumping at $76 \mathrm{l} / \mathrm{min}$ (20 gpm) while the downward flow rate while pumping at 114 1/min (30 gpm) is nearly the same as the ambient flow.

- the hydraulic divide between upward and downward flow at 1,126 $\mathrm{m} \mathrm{bgs}(3,694 \mathrm{ft}$ bgs $)$ is at the same location whether pumping at 76 or $114 \mathrm{l} / \mathrm{min}$ (20 or $30 \mathrm{gpm})$, and

- the borehole interval between 1,126 and 1,149 $\mathrm{m}$ bgs (3,694 and 3,771 $\mathrm{ft}$ bgs) has upward flow under ambient conditions and downward flow while pumping.

Another factor important to understanding these flow logs is the borehole flowmeter calibrated differently in cased and screened zones, indicating the flowmeter was pushing water out through the screen and into the annulus where the lack of a filter pack provided an open conduit. The calibrated flow logs at different line speeds demonstrated very different borehole flow rates. This effect was much reduced when upward and downward flow logs conducted at the same line speed but in different directions were combined. This supports the interpretation that water was being pushed out of the well screen and into the annulus by the moving logging tool.

\section{Fluid Temperature in the Borehole}

Fluid temperature data were collected at the same time as the borehole flow data. These data are examined to reveal additional aspects of the flow regime under pumping conditions. The well was essentially in thermal equilibrium with time and depth under pumping conditions. It is also assumed that changes in thermal gradient are caused by fluid flow and not differing thermal conductivity of the rock. The water temperature during pumping is also used to calculate fluid density and viscosity for fluid pressure estimates.

The temperature log under ambient conditions is provided in Figure 4 and demonstrates two different geothermal gradients. A steep gradient of about 0.0376 degrees Celsius per meter $(\mathrm{d} / \mathrm{m})$ above $1,125 \mathrm{~m}$ bgs $(3,691 \mathrm{ft} \mathrm{bgs})$ and a more moderate gradient of $0.0036 \mathrm{~d} / \mathrm{m}$ below 1,126 
$\mathrm{m}$ bgs $(3,694 \mathrm{ft}$ bgs $)$. The later geothermal gradient is more similar to that of other UGTA wells in carbonate rock at the NTS. There is also a cooler water "temperature indentation" to the geothermal gradient at about $1,126 \mathrm{~m}$ bgs $(3,694 \mathrm{ft} \mathrm{bgs})$. This is the same depth location as the hydraulic divide between upward and downward flow evidenced by the borehole flowmeter. The temperature profile under ambient conditions suggests that cooler water is entering the well at a depth of 1,126 m bgs (3,694 ft bgs).

Fluid temperature while pumping was essentially the same at all discharge rates. The fluid temperature while pumping at $76 \mathrm{l} / \mathrm{min}(20 \mathrm{gpm})$ and under ambient conditions is also presented in Figure 4. Fluid temperatures are apparently slightly cooler under pumping conditions. Cooling of the well during pumping may be explained by cooler water entering the well during pumping. The cooler water could be entering a depth of about $1,126 \mathrm{~m}$ bgs $(3,694 \mathrm{ft}$ bgs) and moving upward and downward with the borehole flow.

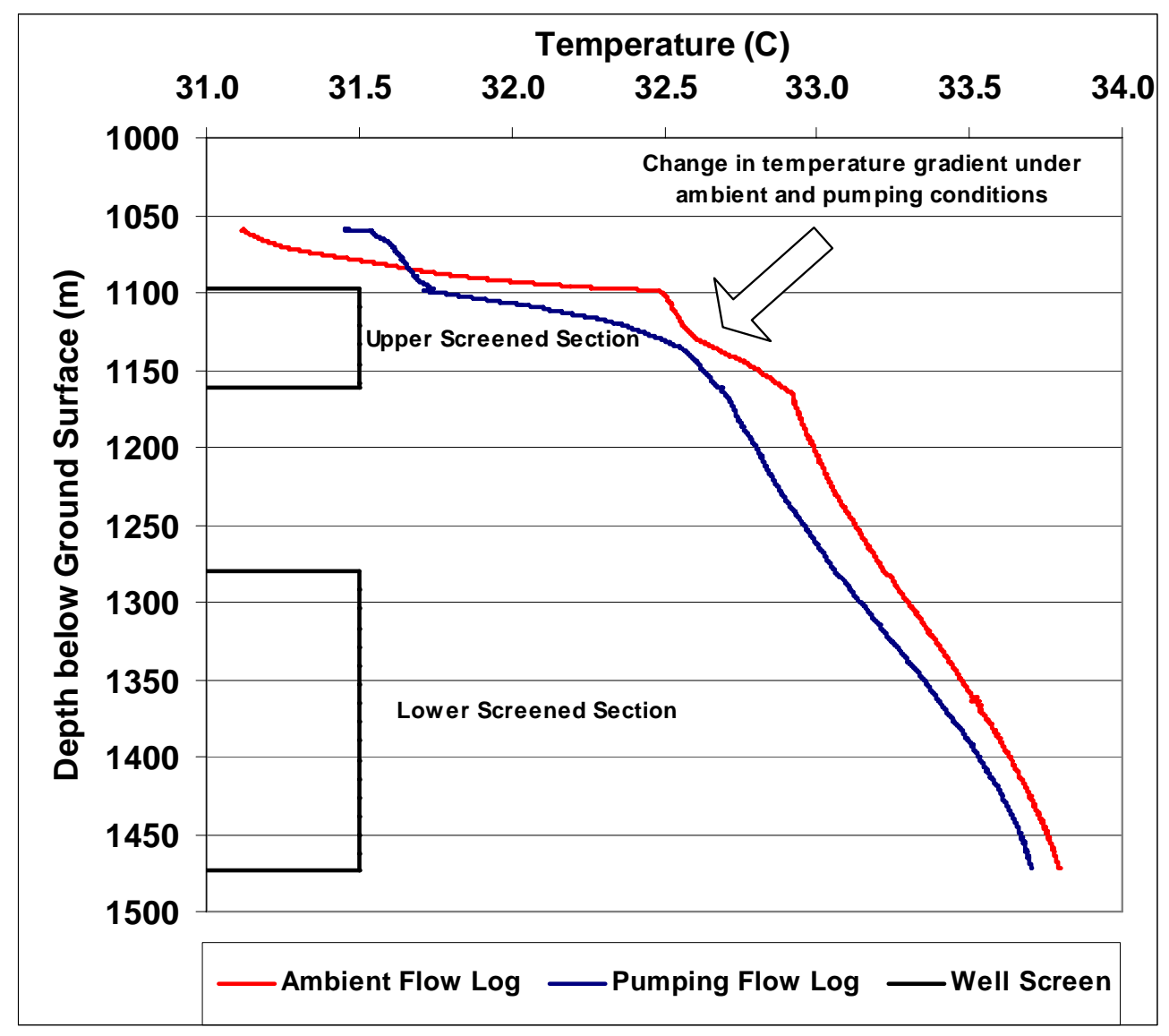

Figure 4. Fluid temperature while pumping.

An alternative, and less likely, explanation is that at least some warmer water is also entering the bore from a location above the upper screened section. This later explanation is in conflict with the borehole flow logs, but could be correct if during pumping there was some cooler water flowing downward in the well annulus while borehole flow was being drawn upward in the upper screened section. Under this scenario, the groundwater entering at 1,126 $\mathrm{m}$ bgs $(3,694 \mathrm{ft} \mathrm{bgs})$ would be cooler and in greater quantity than the water entering from above the 
upper screened section. A change to downward flow direction in the annulus above the upper screened section during pumping would explain the fluid temperature above the upper screened section being warmer under pumping conditions than under ambient conditions.

The ultimate source of the cool water(s) is also unknown and may be from a fracture that intersects a cool water body near the water table or may be from a perched water zone that is cascading water into the well from above the water table at $950 \mathrm{~m}(3,117 \mathrm{ft})$ and below the cement casing seal at $678 \mathrm{~m}$ bgs $(2,225 \mathrm{ft}$ bgs). There are similarities between the thermal profiles of well ER-12-3 and the nearby well ER-12-4. Evaluating the thermal information of these wells may add insight to the understanding of the groundwater and geothermal regimes.

\section{Hydraulic Conductivity at Depth}

The calculated hydraulic conductivity while pumping at 76 and $114 \mathrm{~L} / \mathrm{min}(20$ and 30 gpm) is illustrated in Figure 5. The results are presented as "raw values" and not filtered to remove nonsensical results such as negative hydraulic conductivities. The calculated values are believed to be invalid because of the following reasons:

- flow rates in the well are combination of flow inside the well casing and within the annulus. The absence of a filter pack in the annulus provides an open conduit outside the casing that allows flow rates to be unequal inside the casing and within the annulus. The presence of the borehole flowmeter in the well caused a flow restriction within the well screen that diverted an unknown portion of the borehole flow into the annulus. The amount of flow diversion is apparently dependent on the logging line speed, line speed direction, and the flow rates within the casing,

- there are strong indications from the temperature log that the flow direction in the upper screened section during pumping was upward inside the well screen while it was downward in the annulus. Therefore, the impeller flowmeter readings are not representative of conditions within the aquifer,

- in the upper portion of the screened section, there was a change in flow direction; a strong upward flow under ambient conditions and a downward flow while pumping. This resulted in the calculation of nonsensical negative hydraulic conductivities and can be possibly understood as different flow directions in the well screen and the annulus,

- the decreasing downward flow rate in the lower screened section indicates an interval within the aquifer that is accepting water and has permeability. However, because the ambient and pumping borehole flow rates are so similar, the calculated hydraulic conductivities are essentially zero. This suggests that well pumping had no affect on fluid pressure at depth even though there was 4.75 to $6.8 \mathrm{~m}$ (15.6 to $22.2 \mathrm{ft}$ ) of water level drawdown in the well, and

- the majority of inflow to the well screen occurs at the top of the upper screened section. An unknown amount of this water may be coming from the 417-m (1,368-ft) interval between the bottom of the cement plug at $678 \mathrm{~m} \mathrm{bgs}(2,225 \mathrm{ft} \mathrm{bgs})$ and the top of the upper screened section at $1,095 \mathrm{~m} \mathrm{bgs}(3,591 \mathrm{ft} \mathrm{bgs})$. Assigning this inflow to groundwater production in the aquifer adjacent to the measurement location is an unsupportable assumption. 


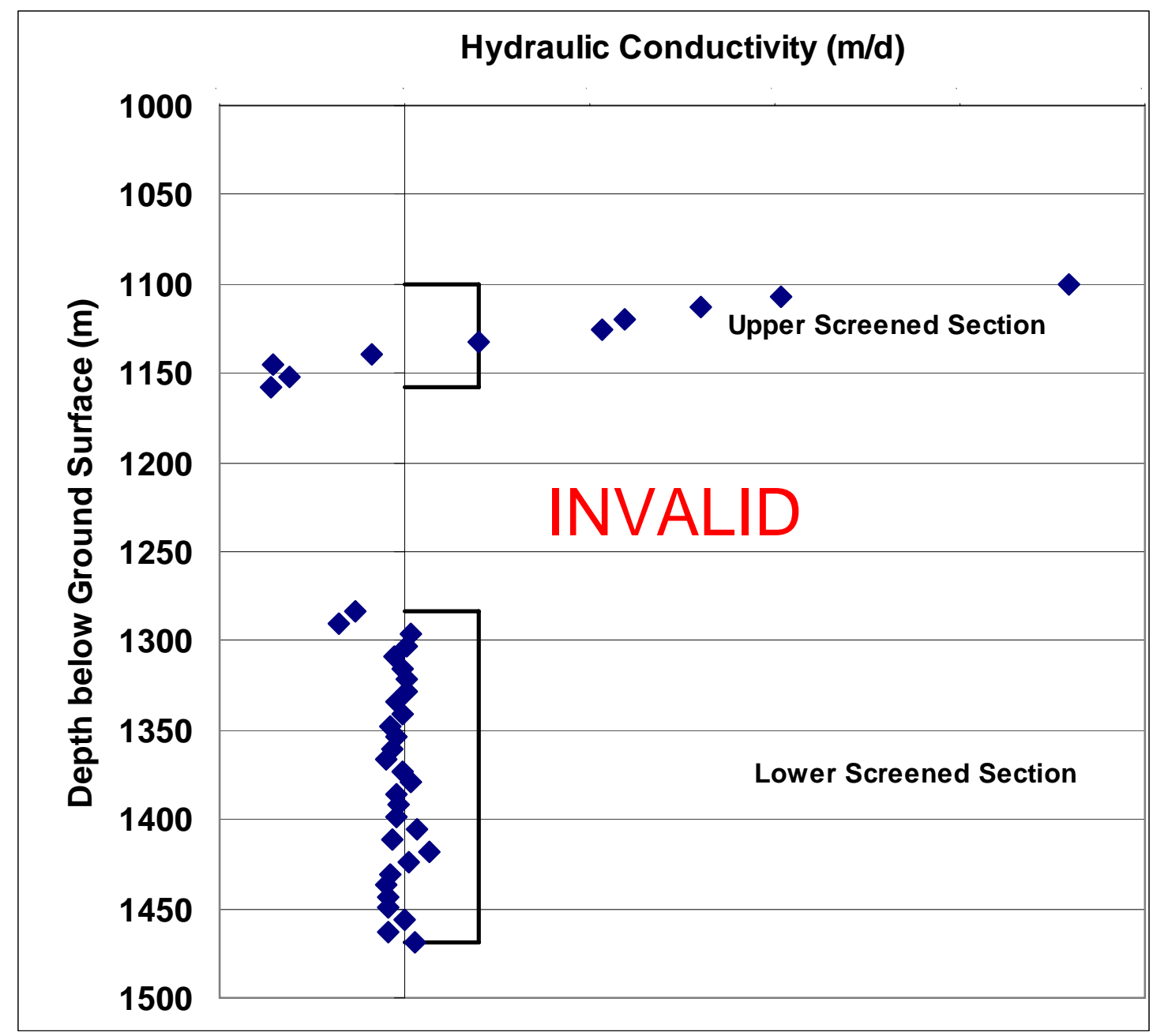

Figure 5. Calculated hydraulic conductivity values.

\section{SUMMARY}

Well ER-12-3 was borehole flow logged under ambient conditions and while pumping at 76 and 114 1/min (20 and $30 \mathrm{gpm})$. A complicating factor to data interpretation is that the well was not filter packed, and there is significant upward and downward vertical flow in the open annulus under ambient and pumping conditions. Ambient flow logging indicates water is entering the upper screened interval at about 1,126 $\mathrm{m}$ bgs $(3,694 \mathrm{ft} \mathrm{bgs})$ and discharging into the lower screened interval. The ambient flow log also indicates that an approximately equal amount of water flows upward into the open section of well bore above the top of the well screen.

The temperature profile under ambient conditions indicates a very steep temperature gradient of $0.0376 \mathrm{~d} / \mathrm{m}$ above $1,126 \mathrm{~m} \mathrm{bgs}(3,694 \mathrm{ft} \mathrm{bgs})$ and a temperature gradient more typical of carbonate rock at the NTS of $0.0036 \mathrm{~d} / \mathrm{m}$ below 1,126 $\mathrm{m}$ bgs $(3,694 \mathrm{ft}$ bgs). During pumping, the temperature profile indicates that cooler water may enter the well at about $1,126 \mathrm{~m}$ bgs $(3,694 \mathrm{ft}$ bgs). Some of this water is discharged by the pump at ground surface and an unknown amount flows downward and reenters the aquifer progressively between 1,277 and 1,473 $\mathrm{m}$ bgs 
$(4,191$ and 4,834 ft bgs). Some warmer water may also be entering from above the upper screened section in the well annulus between $678 \mathrm{~m}$ bgs (2,225 ft bgs).

The open annulus and large vertical flow velocities in the well casing result in the measured changes borehole flow rates being potentially highly nonrepresentative of flow contributions from aquifer. Hydraulic conductivities calculated under these conditions would require unsupportable assumptions and would be subject to very large uncertainties. Borehole hydraulic conductivities are not quantified under these conditions.

\section{REFERENCES}

Driscoll, F.G., 1986, Groundwater and Wells, Second Edition, Johnson Division, St. Paul, Minnesota.

Hubbert, M.K., 1956, Darcy's Law and the field equations of the flow of underground fluids. Transactions of the American Institute of Mining and Metallurgy Engineers. 207:222-239.

Kruseman, G.P. and N.A. de Ridder, 1970, Analysis and evaluation of pumping test data, International Institute for Land Reclamation and Improvement, Wageningen, The Netherlands.

Oberlander, P.L. and C.E. Russell, 2003, Depth-specific Hydraulic Testing of Yucca Flat and Frenchman Flat Environmental Restoration Wells FY 2003, Desert Research Institute, Publication No. 45199.

Rehfeldt, K.R., P. Hufschmeid, L.W. Gelhar and M.E. Schaefer, 1989, Measuring hydraulic conductivity with the borehole flowmeter, Electric Power Research Institute, EN-6511, September 1989.

Vennard, J.K. and R.L. Street, 1975, Elementary Fluid Mechanics, John Wiley \& Sons, Inc., New York. 